\title{
WAREHOUSE RECEIPTS FUNCTIONING TO REDUCE MARKET RISK $^{1}$
}

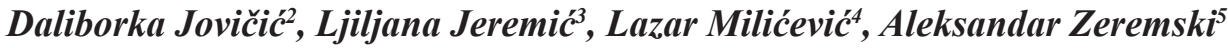

\begin{abstract}
Summary
Cereal production underlies the market risk to a great extent due to its elastic demand. Prices of grain have cyclic movements and significant decline in the harvest periods as a result of insufficient supply and high demand. The very specificity of agricultural production leads to the fact that agricultures are forced to sell their products at unfavourable conditions in order to resume production. The Public Warehouses System allows the agriculturers, who were previously unable to use the bank loans to finance the continuation of their production, to efficiently acquire the necessary funds, by the support of the warehouse receipts which serve as collaterals.

Based on the results obtained by applying statistical methods (variance and standard deviation), as a measure of market risk under the assumption that warehouse receipts' prices will approximately follow the overall consumer price index, it can be concluded that the warehouse receipts trade will have a significant impact on risk reduction in cereal production. Positive effects can be manifested through the stabilization of prices, reduction of cyclic movements in the production of basic grains and, in the final stage, on the country's food security.
\end{abstract}

Key words: warehouse receipts, market risk, variance, standard deviation.

JEL: $P 32, P 42$

1 This paper is part of research project number 179001 financed by Ministry of Education, Science and Technological Development of the Republic of Serbia.

2 Daliborka Jovičić, M.Sc., Coordinator of Statistical Reporting Service, Dunav Insurance Company, Kolarceva Street no. 7, 11000 Belgrade, Serbia, Phone: +381 113037 233, E-mail: daliborka.jovicic@dunav.com

3 Ljiljana Jeremić, Ph.D., professor at University Singidunum, Danijelova street no. 32, 11000 Belgrade, Serbia, Phone: +381 113093 220, E-mail: 1jjeremic@singidunum.ac.rs

4 Lazar Milićević, Coordinator of Assets and Liabilities Risk Management Operations, Kolarceva Street no. 7, 11000 Belgrade, Serbia, Phone: +381 113037 233, E-mail: lazar.milicevic@dunav.com

5 Aleksandar Zeremski, Ph.D., Scientific Associate, Economics Institute, Kralja Milana Street no. 16, 11000 Belgrade, Serbia, Phone: +381 113613 049, E-mail: aleksandar.zeremski@ecinst.org.rs

EP 2014 (61) 2 (347-365) 


\section{Preliminaries considerations}

The creation and development of the warehouse receipts concept is related to the USA. Warehouse Receipt Financing in the USA dates back to the mid-19th century, whereas its importance and further development was inspired by the adoption of the 1913 Warehouse Act. During the last 15 years, significant efforts were made to build-up this type of financing in the EECA ${ }^{6}$ countries as well, by the support of donors, such as the USAID, EBRD and the World Bank.

At the beginning of 1990-ies, in the EECA countries, the banks were experimenting with various types of financing: "The farmers assigned to the banks their right to income from the future corn sales and, in return, the banks granted them funds for immediate financing and/or financing through the particular types of warehouse receipts". In some countries, warehouse receipt financing was based upon the Soviet ere Form 13 Warehouse Certificate ${ }^{7}$ (See more at: Hollinger and Rutter, 2009) and the collateral management by banks and/or their agents.

The banks and merchandisers found their way of using the warehouse receipts as a part of financial structure. In the past 10 years, the banks granted large funds based on the "quasiwarehouse receipts" (Form 13 - Warehouse Receipts dominant in Russia, Ukraine and Kazakhstan). With these receipts, the banks were able to control the goods; however, the depositor had too wide authorizations in handling the goods, which made the loan uncertain for the bank.

The Public Warehouses System has shown especially successful in the EECA, where farms have no loan history and only poor funds to offer as collateral. The EBRD has promoted the development of the relevant regulatory and institutional framework, and they invested into the banks that were willing to use the warehouse receipts based on the stored agricultural products as collateral for granting loans to the local agricultural producers.

The defined Support Programme, developed by the EBRD, has two following main goals:

- Passage of experience and knowledge from the Central Europe, regarding the warehouse receipts issued on the basis of stored agricultural products;

- Analysis of the current legal frameworks of a country and suggesting and requiring their improval.

In favour of the above mentioned, there are some successful examples in the countries like Bulgaria, Hungary, Slovak Republic and Ukraine. These countries recorded a permanent recovery of the agricultural production as a result of implementation of the Warehouse Receipts Programme (WHRP) but also, to a large degree, thanks to the improved macroeconomic situation, political stability and favourable weather conditions.

6 EECA - Eastern Europe and Central Asia.

7 The Warehouse FORM 13 existed in the countries of the SSR, in the form of the store notes certifying that the goods were received on store. The basic relevant law did not allow for the receipt to be used as collateral. 
The implementation of the licensed warehouses concept and the adoption of the necessary laws are of multiple importance and they affect more than one sector (directly or indirectly included in the system). We shall mention only a few most important effects bellow (Stanković, 2010):

- Secure storage for the agricultural products, allowing the farmers to define the most favourable period for selling their products without being blackmailed by the wholesalers,

- Possibility for the farmers to get a more favourable loan for the procurement of row material and machinery and to purchase land by offering the warehouse receipt as collateral,

- Multiple protection of depositors, ensuring the quality and quantity of the goods placed on store,

- Increased liquidity of the agricultural system in the cases where the land cannot be used as collateral,

- The Integration of domestic market into the regional and world markets, the enhancement of daily trade of stored goods and attracting more investors,

- Providing basis for the financial derivatives market development,

- The System enables the banking sector to enter a broader market at a smaller risk (high level of collateral protection).

The basic aim of introducing the System of Licensed Warehouses and Warehouse Receipts is to offer the alternative to producers and processors in deciding about the short term financing, since they would be able to offer the stored goods as collateral (warranty, means of insurance). In the previous practice, the farmers had no much choice in financing the sowing and the agro-technical measures. Often, the land could not be used as loan collateral, because of the outdated land registry and the difficulties in determining the rights of land ownership. Alternatively, the farmer could exchange his goods for the materials needed to continue the production or sell them, in a need, at any price offered. Such long-term practice covered up the actual costs and values of the products, i.e. the farmers did not get the real market value for their products; instead, their potential profit was redirected to other people.

In that sense, the System of Licensed Warehouses and Warehouse Receipts proposes a different practice, which should contribute to the development of agriculture by offering the goods collateral as a solution for the long-standing problem of short-term financing. On the other hand, the System of Licensed Warehouses is important for the firms dealing in buying and further processing of agricultural products, because it allows them to protect against the risks of unexpected cyclical price fluctuations of agricultural products by buying goods in advance and, in this way, efficiently plan the cost price of final products. The farmers, on the other hand, would get the money in cash and not rely upon the bank loans to prepare for the next sowing. 
The multiple protection of depositors is inevitable, in a sense of ensuring the quality and quantity of the goods placed on store. Under the adopted Act on Licensed Warehouses for Agricultural Products, a licensed warehouse shall be obliged to compensate a holder of a warehouse receipt for the damage incurred upon the goods on storage; if they fail to do so, the compensation shall be paid by the Compensation Fund. The basic aim of the Compensation Fund is to provide, through the additional insurance coverage, the additional guarantee to the owner of goods and/or creditor that they will collect their claims. The licensed warehouses shall also be obliged to take out the insurance coverage, with the authorized insurer, for the basic assets and the goods on store against the risks of flood, fire and theft.

The spreading of bank credit lines to include the financing of activities of small agricultural producers has, up to now, been very modest, due to the high costs of acquiring the borrower's credit history and the lack of movable collateral, as well as the non-regulated land ownership structure. The problem has become more complicated due to the nonexistence of loan investments and the lack of educated staff in banks, able to assess the credit rating of the potential borrowers. On the other hand, a small number of farmers and/ or farmlands own the expertise to compose the investment plans needed to get the loans. The System of Licensed Warehouses stimulates banks to grant loans to farmers, by using the warehouse receipts as collateral, as well as by forming the Compensation Fund (to fulfil the commitments of the public warehouses). The precondition for this is to adopt a clear legal framework, which would, among other things, regulate the compulsory liquidation of stocks on the basis of a warehouse receipt if the loan becomes uncollectable in due time, thus allowing the banks to properly invest their funds at a minimum risk.

By means of warehouse receipts, the system of licensed warehouses stimulates the development of the commodity-based financial markets; this is very important for Serbia, because of a long tradition of agricultural production. In this way, a large number of financial institutions, broker and dealer companies and investment funds are allowed to make the risk dispersion by investing into the commodity credit instruments.

\section{Warehouse Receipt as Security Paper}

The commercial bills with commodity coverage and/or warehouse receipts represent the securities which guarantee that the goods in question are of the claimed quality and quantity on storage.

Depending on whether the warehouse receipt consists of one or two parts (the docket and lien warrant), there are two concepts. The first concept applies under the AngloAmerican legal system (USA, Great Britain), while the second is present in the countries with continental legal system (including Serbia). The essential difference between the two concepts is in proving the ownership over the goods, i.e. whether any one or both documents (the docket and lien warrant) are needed to that purpose. Speaking about the warehouse receipt consisting of two parts (the docket and lien warrant), the holder of the docket has no right to take the goods from the warehouse (it is protected by the 
lien part of the warehouse receipt), until the full repayment of the loan secured by the goods collateral and/or the lien warrant. The holder of a lien warrant is entitled to the value of collateral equalling the amount of debt and the accrued interest. The docket and/or the lien warrant can both be the subject matter of a separate trade (i.e. they can be traded with independently); this refers to the exchange business, as well. The warehouse receipt can be issued in both written and e-form.

The warehouse receipt is divisible, i.e. can be divided into multiple warehouse receipts in exchange for the already issued warehouse receipt and vice versa. The depositor may require of the warehouse to split the goods into particular portions and issue a separate receipt for each portion. The warehouse receipt is usually valid for up to one year, i.e. its validity cannot exceed the life of the agricultural products.

In case of a two-part warehouse certificate, the warehouses can issue the goods only after the reception of both its parts (the docket and lien warrant). The holder of the docket can be issued the goods only if the debt has been fully repaid, pursuant to the contract, which must be supported by adequate documentation. The holder of the docket may require that he be sold the goods if the actual selling price can cover the debt and/or pay off the holder of the lien warrant and cover the storage expenses, provided that he gets back the realized surplus. The warehouse receipts can be traded with both at the stock exchange market and outside it, in a public auction and/or through a direct offer.

The following securities are used in commodity exchange, as instruments in the goods trade:

- commercial bills with commodity coverage or warehouse receipts,

- time sales contracts (forward contracts, futures contracts and option contracts).

Warehouse receipt can be widely applied as an instrument of ownership transfer in transactions with futures contracts and in the spot trade. In this way, the creditor is insured i.e. he has a secure collateral in a form of warehouse receipt.

In order to protect against the product price fluctuations, the warehouse receipts may be combined with hedging instruments. Hedging is a method of using derivatives (derivative securities) by means of which an individual or an enterprise ensures a minimum price for its products (as well as maximum purchase price), by using a set of transactions, available on the financial market (Stojanović, 2000). Classical example of hedging is the purchase of a particular time contract for the delivery of a particular commodity at a precisely defined future date. IMF recommends, above all to the developing economies, to use the hedging instruments in their export arrangements, in order to keep the risk of fluctuation of the basic product price, interest rate and foreign currency exchange rate under control (Mathieson et al., 1989). Kenya and Uganda are among the countries that often use the combination of warehouse receipts and hedging, especially in financing the coffee exports.

The most important form of exchange business is trading with futures. Actually, trading with futures represents the link between the commodity and financial markets, enabling the control of the possible risk occurrence due to the fluctuation of interest rates, foreign 
exchange currency, price of shares and bonds etc. The agricultural producers have a natural aversion towards the price fluctuation risk and they find it very attractive when it is possible to agree on the price of agricultural products in advance and ensure a minimum return on the sales contracts. On the other hand, the producers who use the agricultural products as the production inputs can include their expenses, in advance, into the cost price of final products.

By concluding the time contract, the market risk and/or the price fluctuation risk is not fully avoided, only minimized. The risk of force major or credit risk are always present (risk of default by any contracting party). Therefore, when concluding such contracts, there is always a third party - a clearing company which protects time contracts against the credit risk.

The functioning of futures market is of multiple importance for the increase of the total economic efficiency of a country and the increase of the degree of stability and balance of the agricultural production. The short term investments into the agricultural production would also improve the Serbian food processing industry (see more in: Stojanović, 2000).

The preconditions for successful functioning of the Commodity Exchange and its development are:

- macroeconomic stability of a country,

- depth of the stock exchange market,

- market liquidity and price fluctuations.

Macroeconomic stability of a country is a precondition for the investors and their investments, since it additionally lowers the risk of investing into a particular country. The factors for maintaining the macroeconomic stability of a country, such as the stability of domestic currency, balanced prices and interest rates are crucial for meeting the conditions for the development of stock exchange business.

Market depth implies a lot of financially powerful players on the commodity-stock exchange market, both the sellers and the buyers, which provides for the price stability. The insufficient market depth leads to the market instability and encourages the speculators.

Market liquidity influences the movements of prices on the market. The increased market liquidity means reducing the market risk. In order to achieve the appropriate market liquidity, it is necessary to have a sufficient number of the institutional and individual investors on the market. In addition to commercial hedger, there are also arbitragers and speculative dealers on the Commodity Exchange, ready to take over the risk of price fluctuations. Bigger number of players on the Commodity Exchange leads to a better market liquidity.

Trading with futures contracts calls for minimum price fluctuations - on the contrary, if the prices remain unchanged and/or only slightly changed over a longer period of time, there is no need for a trade with futures contracts. This comes out of the fact that the trade with futures contracts is done only to protect the stock exchange participants against the future price fluctuations (Dunković, 2009). 
On the basis of experience in trading with shares and other corporate securities on the financially organized market, it is necessary to provide for the dematerialization of warehouse receipts, which implies the existence of the electronic data basis. The advantages of dematerialized warehouse receipts, i.e. the e-warehouse receipts are: abolishing of hard copy warehouse receipts, requiring complicated recording and filing processes, faster information exchange and the reduction of theft risk.

\section{Opportunities and Threats for Banks and Agriculturers Trading in Warehouse Receipts}

Implementation of the Public Warehouses System and using the warehouse receipts as collateral or as a security paper in trading on the Commodity Exchange carries both opportunities and threats, for all the participants in the system chain. Some of them are listed below:

Picture 1. Opportunities and Threats for Banks Trading in Warehouse Receipts

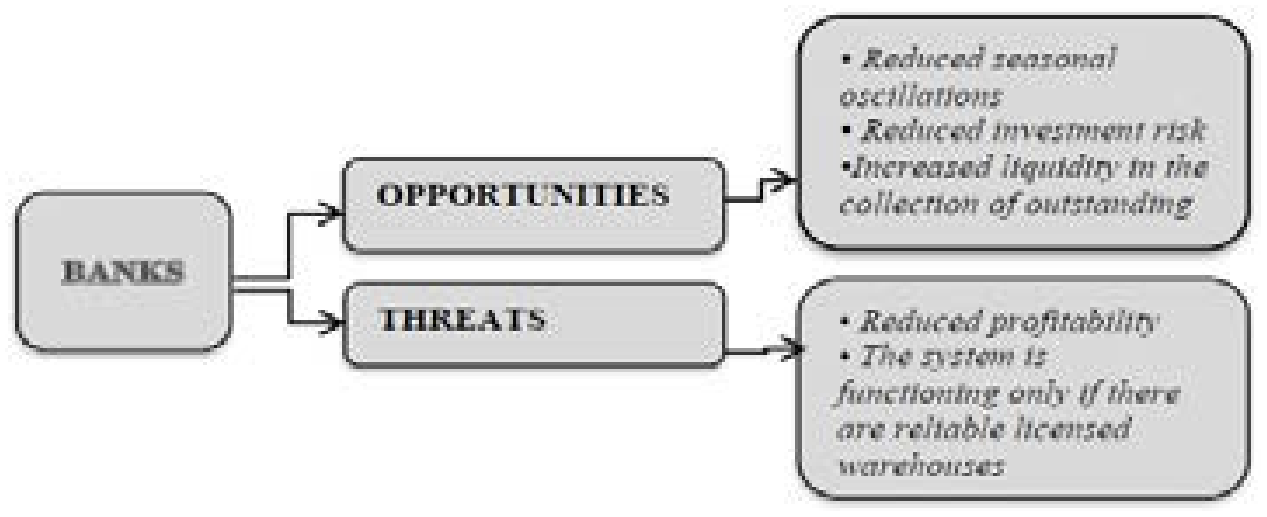

Source: Author's Analysis.

The reduction of investment risks through the possession of the warehouse receipt as collateral (especially important for new bank clients, having no credit history) and the reduction of seasonal price fluctuations increase the liquidity of banks, which is especially important for those banks having difficulties in the collection of debts (it is easy to en-cash a warehouse receipt, either in a bank or by selling it at the stock exchange).

The threats for the banks are reflected in the reduction of interest rates, which may give rise to the reduction of profitability. However, a warehouse receipt functioning as collateral adds to the reduction of the risk of investing into loans to agricultural producers, at the same time lowering the bank interest rates. The trust of banks towards the investments into loans based on the warehouse receipts is possible only if there are reliable, licensed warehouses with concluded Professional Liability Insurance coverage for the stored agricultural products. 
Picture 2. Opportunities and Threats for Agriculturers Trading in Warehouse Receipts

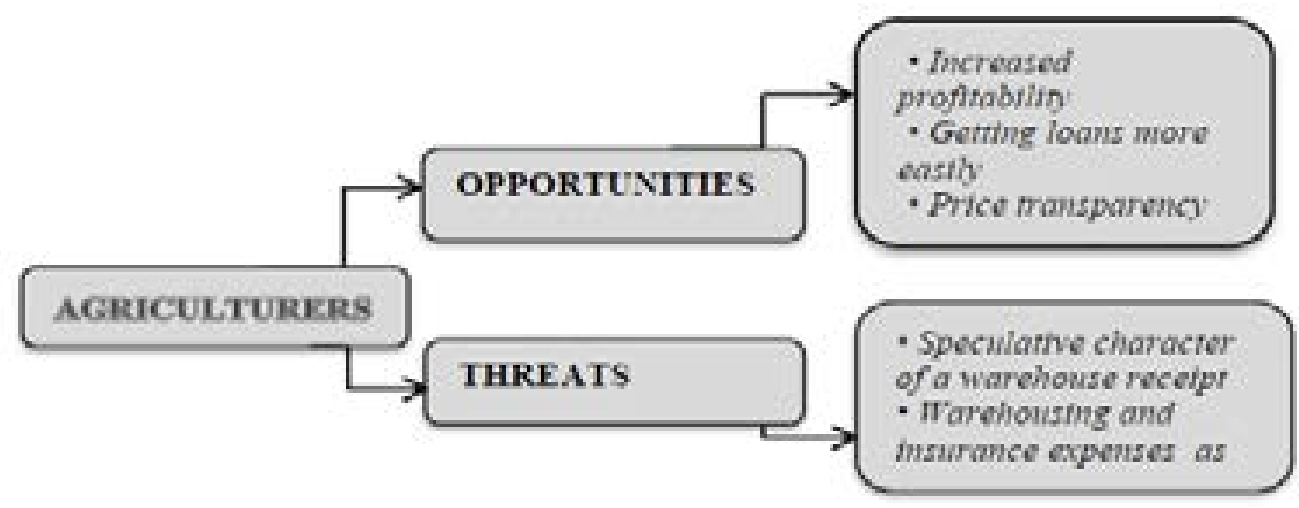

Source: Author's Analysis.

The business profitability of agriculturers has grown through the possibility to postpone the sale until the price of the agricultural products is increased. The price transparency is ensured by the stock exchange trade. A warehouse receipt functioning as collateral makes it easier for the agriculturers to get the bank loans needed for the uninterrupted cycle of the agricultural production. The advantage of using the warehouse receipts for the export-designed products is very important, since it enables the holder of a receipt to borrow abroad, in a foreign currency at a lower real interest rate. In this way, the holder of a warehouse receipt is protected against the currency risk when borrowing abroad, using the export products as collateral.

The threats reflect in the speculative character of the warehouse receipt (the producers wait for the best price on the market, the increased price leads to the increased offer and, at one moment, the prices fall and the profit decreases). Moreover, the storage and the professional liability insurance represent the additional expenses for agriculturers.

A warehouse receipt is a security paper and, as such, enables the transfer of the goods ownership. Therefore, it plays an important role in the international goods turnover, helping to reduce the transportation costs and avoid the unnecessary and often expensive goods transportation.

\section{Positive Examples of Implementation of Warehouse Receipts Programme in Neighbouring Countries}

Successful examples in the Region, where the European Bank participated in the implementation of the WHRP (Warehouse Receipts Programme) are Bulgaria, Hungary, the Slovak Republic, and the Ukraine. These countries report a constant recovery of the agricultural production as a result of the implementation of the WHRP but also, to a large degree, thanks to the improved macroeconomic situation, political stability and favorable weather conditions.

- In 1999 Bulgaria, when the EBRD got involved into the implementation of the WHR Programme, the Warehouse Receipts Law had already been adopted. The drafting of the Law 
was largely supported by the Agency for International Development (USAID) and World Bank. The European Bank signed the Memorandum of Understanding, as of $26^{\text {th }}$ July 1999 , thus supporting the intention of the government to fully implement the Warehouse Receipts Law, including the formation of the Compensation Fund. To that effect, it became obliged to provide for the WHR System implementation financing via the local banks, following the implementation of the Law. After a successful implementation of the Law on all levels and the formation of the first Compensation Fund in the Region in 2000, the European Bank actively participated in granting the loans, during a consecutive period of 3 years. Bulgaria is one of the most successful countries, which, by introducing the Public Warehouses System achieved an extraordinary success in boosting the warehousing capacities and developing the lines of credit granted through such a System. This is also seen from the fact that in the year 2000, when the System was officially introduced, there were $250.000 t$ of warehousing capacity and 22 public warehouses in Bulgaria. This number swiftly increased, so that in 2009, Bulgaria had 47 authorized warehouses and the warehousing capacities grew to $500.000 \mathrm{t}$. Such a progressive growth of the warehousing capacities brought about the increase in the amount of loans granted by the support of this System, reaching to over 70 million dollars (Hollinger and Rutter, 2009)

- Hungary, under the 1996 Act, oriented its Public Warehouses System on export-designed products, such as wine, sugar, fertilizers and, above all, the grains. The export subsidies granted by the Hungarian government inspired others to get involved in the Public Warehouses System; a large number of banks started financing the export products. Since the adoption of the Public Warehousing Act, Hungary made the biggest step ahead in the development of the warehouse receipts in the Eastern Europe. Hungary is the first country in the Region to have completely implemented a specific legal framework regarding the warehouse receipts. The European Bank, however, never took active participation in granting funds against the store notes (although there were a few calls for cooperation by local banks), nor participated in the implementation of the legal regulations. The loans granted under this programme are very popular in Hungary and both local and international banks are very interested in a warehouse receipt as a pledge instrument in granting loans to agriculturers (EBRD, 2004).

- Slovakia is the first country where the European Bank participated in granting the loans secured by a warehouse receipt as collateral. In addition to the European Bank, an important role in the warehouse receipt financing has been played by the Agricultural Bank and the SFMR (State Fund for Market Regulation), through which about 55 million dollars have been invested in the market. Whereas the European Bank accounted for the technical support (financed by Taiwan), in the sense of providing the Agency for Issuing Licenses with the staff and their training, the SFMR has had an important role in covering the risk of exchange rate fluctuations of the Slovak currency. Nowadays, the European Bank has ceased with its active participation in granting such kind of loans in Slovakia. However, since a successful implementation of the WHRs in 1998, the European Bank took active participation during the four subsequent uninterrupted seasons (Hollinger and Rutter, 2009). 
- Ukraine has joined the countries implementing the Licensed Warehouses System and issuing the WHRs in 2002, after they made major efforts to that aim supported by the EBRD and USAID. This country has implemented a sound Warehouse Receipt Act which especially regulates the stored grain. The Ukraine, the first country in the Region to have introduced a Central Electronic WHR Register, owns 500 licensed warehouses and more than 26 million tons of storage capacity. The initial enthusiasm of financial institutions for the big opportunities offered by the Ukrainian grain market inspired the EBRD to invest 500 million dollars by way of warehouse receipt financing, but the country was unable to adopt an efficiency guarantee mechanism during the initial phase of the programme. Although two state-owned licensed warehouses went bankrupt in 2005, this did not discourage the international financial institutions from credit financing (Hollinger and Rutter, 2009).

- Unlike other countries in the Region, Serbia adopted the Public Warehousing Act only in 2009 (Službeni glasnik br.41, 2009). A Manual was issued for the operation of the Public Warehouses of grain cultures and the warehouse receipts, issued by the Public Warehouse (Mastilović et al., 2011), were introduced as a marketable material, under the Annex to the Rulebook on Stock Exchange Trade on Novi Sad Commodity Exchange. Traditionally, Serbia has a strong agribusiness sector and is amongst the leading countries in the Region when it comes to the agricultural production. A big money support of the European Bank for Reconstruction and Development is expected for this segment. This has been supported by signing a Protocol between the Serbian Ministry of Agriculture and the EBRD for providing the money support in the implementation of the WHR System. The EBRD support means that they will, through commercial banks, invest money for financing the Public Warehousing Programme. Direct long-term financing by the European Bank has been provided for the big agricultural producers, whereas the small and medium-sized enterprises will be financed through the special-purpose credits granted by local banks. Since the adoption of the Public Warehousing Act, 15 Serbian grain warehouses, of 91.716 tones available store capacity, were issued licenses (Kompenzacioni fond). Having in mind that, in 2012, 1.910.914 tons of maize and 3.532.602 tons of corn were produced (Serbian Statistical Office, 2013), it is necessary to dedicate certain funds to the technical and technological improvement of the existing warehousing capacities and include them into the system, as soon as possible. In this way, it would be possible to avoid the monopoly of few licensed warehouses in setting the storage prices and satisfy the storage requirements of many agricultural producers.

In order to establish a trade in derivatives in Serbia and make the futures market functioning, the following conditions have to be fulfilled (Stojanović, 2000):

- existence of marketable material and a market attractive enough for a term trade in these assets,

- readiness of the economic entities for a term trade, with a view to insuring the basic assets against the price fluctuation risk and achieving the attractive gain by those able to invest their free capital in this way,

- existence of the appropriate legal and regulatory infrastructure (the supreme 
legal document regulating the securities turnover, stock exchange and dealings in stocks, and the rulebooks on the transactions on particular stock exchange markets and their regulatory authorities),

- developed trade model (system), implying an adequate information technology, the procedure of transactions netting-out and market administration, supported by the knowledge of trading in futures.

The government, as a creator of social and economic climate, is crucial for the development of trading in futures. For the functioning of trade in futures, in addition to adopting clear legal regulations, it is necessary to implement a macroeconomic reform targeting, above all, the price deregulation and stabilization, which would spur the market orientation and entrepreneurship.

Slovenia is a positive example to have achieved, in a process of transformation, a big-scale turnover in trading with securities without having had a developed capital market. Actually, the strong presence of market economy logics and endeavours to join the EU integration processes brought about a big-scale trade in financial derivatives, in spite of the fact that the economy transformation process was yet uncompleted (the lack of legal regulations, low market liquidity etc.). This is added to by the fact that Slovenia developed individual systems of electronic trade, clearing and information sharing through the Internet network (Stojanović, 2000).

However, the trading in warehouse certificates shall only become popular if the potential buyers gain trust in the system. This highlights the importance of a due licensing and inspection of the warehouses permitted to issue the warehouse receipts. The monitoring system must provide protection against the frauds and ensure that only one party is entitled to the collateral, at any moment.

\section{WHR as Instrument for Reducing Price Risk of Strategic Agricultural Products}

By analysing the maize price movements on the Novi Sad Commodity Exchange, during the five-year period (from 2008 to 2012), a clear cyclical pattern can be observed, for each year i+ure of dispersion, it can be observed that the price of maize varies drastically during each observed year:

Table 1. Maize Price Variation Interval per Annum

\begin{tabular}{|c|c|c|c|c|c|}
\hline \multirow{2}{*}{ Year } & \multicolumn{2}{|c|}{ Maximum price } & \multicolumn{2}{|c|}{ Minimum price } & \multirow{2}{*}{$\begin{array}{l}\text { Variation Interval } \\
\quad I=x_{\max }-x_{\min }\end{array}$} \\
\hline & Date & Amount & Date & Amount & \\
\hline 2008 & 18.1. - 20.1. & 16.67 & 15.10 & 7.04 & 9.63 \\
\hline 2009 & 2.6 . & 12.23 & 8.1. & 7.40 & 4.83 \\
\hline 2010 & 19.9.-29.8. & 23.00 & 1.1.-4.1. & 10.20 & 12.80 \\
\hline 2011 & 19.7 . & 23.56 & 10.10. & 14.80 & 8.76 \\
\hline 2012 & 20.9 . & 27.13 & 1.1. -4.1. & 15.50 & 11.63 \\
\hline
\end{tabular}

Source: Author's Analysis according to Produktna berza Novi Sad. 
The intensity and dynamics of variation depends on a variety of factors (the quantity of maize harvested in the current and/or previous year, the crop expectations in the current year, state interventions on the market, limitations to maize import and export and the like).

In addition to the annual cyclical movement, there is also a trend rate of average price growth during the entire five-year period, which can be observed from the graphic representation of daily price movements on the Novi Sad Commodity Exchange:

Graph 1. Maize Price Movements on Commodity Exchange

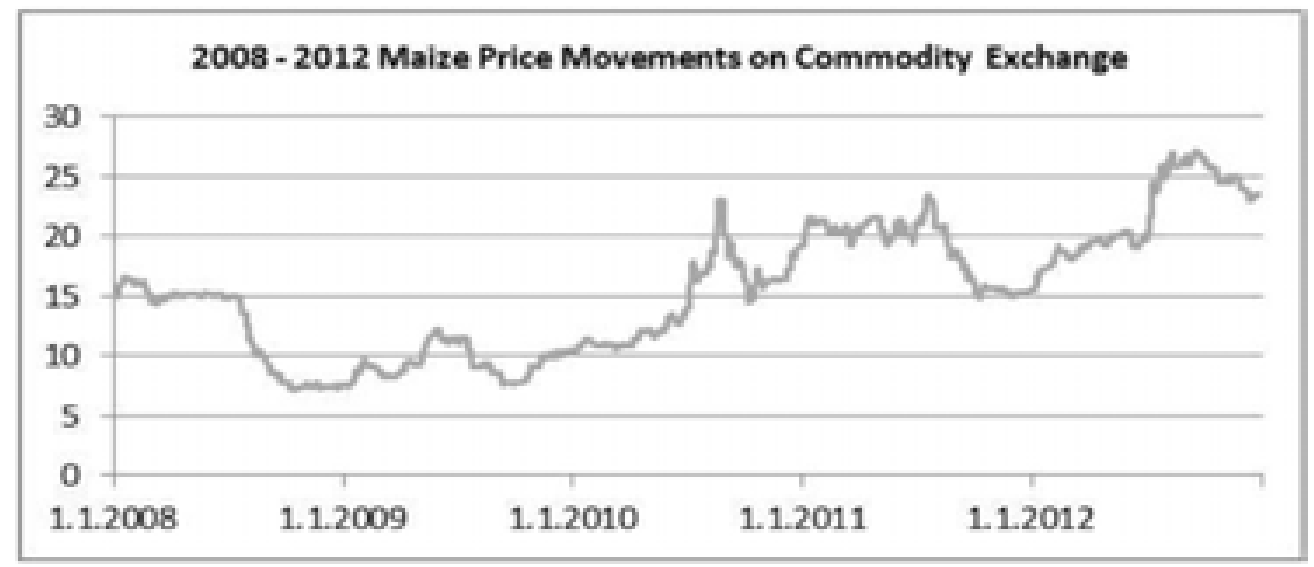

Source: Author's Analysis according to Produktna berza Novi Sad.

The price movements in time have a particular dispersion, difficult to approximate by a theoretical model in order to attribute an adequate probability to a particular price. Starting from the assumption that all displayed prices in a time series have the same unvariable probability, the expected $\mathrm{E}(\mathrm{x})$ price value can be expressed as:

$$
E(x)=\bar{x}=\sum_{i=1}^{N} \frac{x_{i}}{N}
$$

Where $x_{t}$ represents the price at $t$ moment, $t$ assumes the values of $1,2,3, \ldots, \mathrm{N}-1, \mathrm{~N}$, whereas $\mathrm{N}$ stands for a total number of price observations within a particular period.

The variance and/or standard deviation is a measure of deviation of an amount from the mean value. The variance and/or standard deviation, representing the deviation of a random variable price from its mean value, expressed in the same measurement units, can be expressed as (Muminović et al., 2013):

$$
\operatorname{Var}(\mathrm{x})=\sigma^{2}=\sum_{\mathrm{i}=1}^{\mathrm{N}} \frac{\left(\mathrm{x}_{\mathrm{i}}-\overline{\mathrm{x}}\right)^{2}}{\mathrm{~N}-1}
$$

and is reached at by summing up the squares of unit price deviations from the mean values $n$ number of observations reduced by $l$, where $\mathrm{N}-1$ is taken for the reduction by one 
degree of freedom and/or for the assessment of one additional parameter in the denominator - mean value. In this way, we get the so called impartial assessment of the basic set - in this case, the set of maize prices.

Standard deviation, as a risk measure, is an absolute indicator and it will, as a rule, be higher for the series with higher price variability and lower for the series with lower price variability. It is suitable for comparison, provided the compared series have the same arithmetic mean (expected price); when comparing the series with different arithmetic mean, however, we would use the relative dispersion indicator and/or the variation coefficient CV (Muminović et al., 2013):

$$
\mathrm{CV}=\frac{\sigma}{\overline{\mathrm{x}}}
$$

For the observed five-year data series, the price variability during the period of five years can be determined as measured by variance, standard deviation and variation coefficient:

Table 2. Mean Value and Maize Price Variability Indicators per Annum

\begin{tabular}{|l|r|r|r|r|}
\hline \multicolumn{1}{|c|}{ Year } & Mean Value & Variance $\boldsymbol{\sigma}^{\mathbf{2}}$ & \multicolumn{1}{c|}{$\begin{array}{c}\text { Standard } \\
\text { Deviation } \boldsymbol{\sigma}\end{array}$} & $\begin{array}{c}\text { Variation } \\
\text { Coefficient } \mathbf{V}\end{array}$ \\
\hline $\mathbf{2 0 0 8}$ to 2012 & 15.42 & 29.44 & 5.43 & 0.35 \\
\hline $\begin{array}{l}\text { 2008 to 2012 (monthly } \\
\text { average) }\end{array}$ & 15.49 & 29.09 & 5.39 & 0.35 \\
\hline $\begin{array}{l}\text { 2008 to 2012 (monthly average } \\
\text {-general index) }\end{array}$ & 20.29 & 7.28 & 2.70 & 0.13 \\
\hline
\end{tabular}

Source: Author's Analysis according to Produktna berza Novi Sad, http://paragraf.rs/ statistika/26 stat_arh.htm

If the named indicators are calculated for the total five-year period, by using both daily prices and average monthly prices, the variation coefficient is the same $(0.35)$, and the mean value, variance and/or standard deviation is almost identical in both cases.

If we had the WHR market, the price movements of such securities would show the ratio between the variability of maize prices freely formed on the commodity market and the price of warehouse receipts on the financial market. Since there is no trade in warehouse receipts on the market, we have used, in the further analysis, the monthly indices of consumer prices (retail price indices before 31.12.2010) as a basis for determination of benchmark prices that could replace the WHR prices. The assumption is that the movements of the warehouse receipts supply and demand, and deferment of their sale until the satisfactory selling price is obtained would lead to the price movements approximating the general price index. The Graph 2 shows the movements of average monthly maize prices and average monthly prices formed on the basis of general price index movements (growth of consumer prices) ${ }^{8}$.

8 We took, as the initial price, the price of maize on the Novi Sad Commodity Exchange as of 1.1.2008, to the amount of $16 \mathrm{din} / \mathrm{kg}$ (index 100).

EP 2014 (61) 2 (347-365) 
Graph 2. Movements of Average Monthly Maize Prices on Commodity Exchange

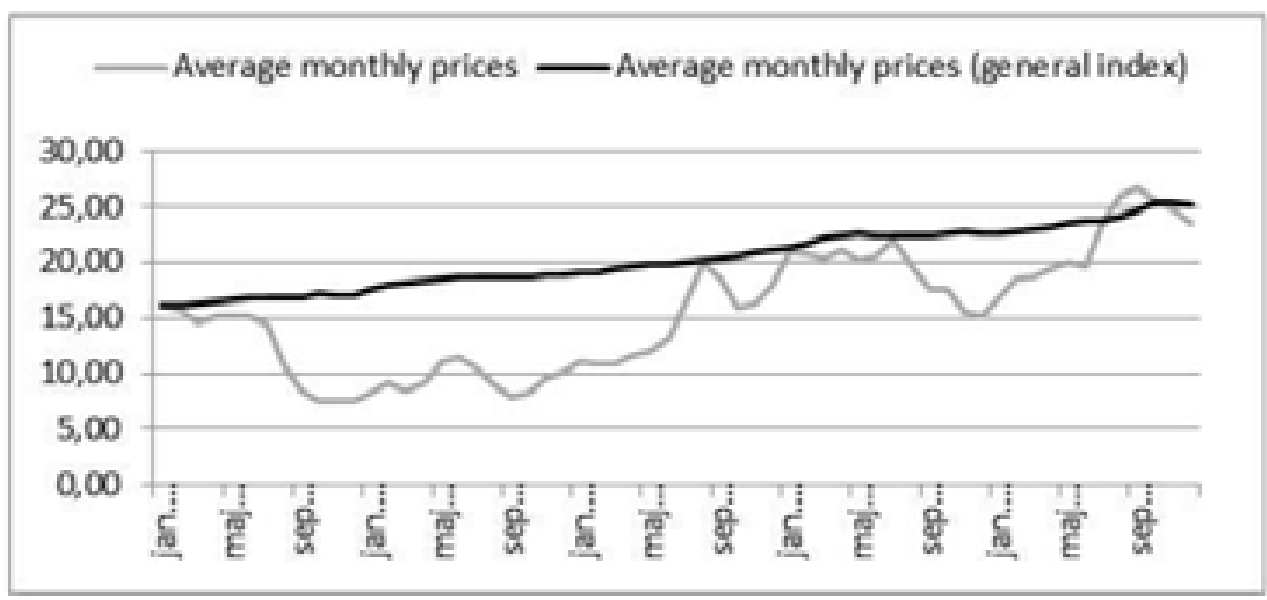

Source: Author's Analysis according to Produktna berza Novi Sad, http://paragraf.rs/ statistika/26_stat_arh.htm

The Graph above shows a much higher stability of price movements when the prices are formed by applying the general consumer price index as opposed to average monthly maize prices. The price stability can be measured by standard deviation as a variability measure. On the basis of variation coefficient computation, the price variability defined on the basis of general indices is by approximately 2.7 times lower than the variability of prices formed on the commodity exchange. During the almost entire five-year period, the level of prices formed by the application of the general index has been higher, compared to the level of average monthly maize prices formed on the commodity exchange. The mean value, in this case, is by over $30 \%$ higher than with the prices formed on the commodity exchange, which significantly exceeds the contingent expenses (of storing, insurance and interest), since these expenses are limited by the government imposed measures and a part of them is subsidised ${ }^{9}$. It is especially important to keep in mind that the period of warehousing and/or issuing the warehouse receipts should not exceed one year. The maize price movements can be observed not only with regard to variability, but also to price volatility, i.e. the frequency, speed and amount of price trend fluctuations during the observed periods. The starting point for determining the volatility is the expression of price movements through the price fluctuation rates. Price fluctuation rate is expressed in percentage price growth between two periods, i.e.:

9 Under the Enactment of Stimulative Funds for Subsidizing the Warehousing Expenses (Official Gazette of the RS No. 46/10), the agricultural producers have become entitled to the stimulative funds of 50 to 70 dinars per tonne, for the storage of wheat, durum wheat and maize in 2010, and under the Enactment on Developing Programme for Subsidising Interest on Short-Term Financing of Agricultural Production (Official Gazette of the RS 6/10), the maximum rate was determined for the warehouse receipt loans, to the amount of the NBS reference rate plus $3 \%$, without currency clause, and the interest was partially subsidised, to the amount of the NBS reference rate. 


$$
r_{p i}=\frac{\mathrm{P}_{\mathrm{i}}-\mathrm{P}_{\mathrm{i}-1}}{\mathrm{P}_{\mathrm{i}-1}} * 100
$$

Where:

$\mathrm{r}_{\mathrm{pi}}$ - represents the price fluctuation rate expressed in percentages during the $i$ period $\mathrm{P}_{\mathrm{i}}$ - price of the current period

$\mathrm{P}_{\mathrm{i}-1}-$ price of the previous period

The movements of monthly maize price fluctuation rates on the Commodity Exchange and the fluctuations of monthly maize prices formed on the basis of general price index can be shown in a short form.

Table 3. Rates of Fluctuation of Average Monthly Maize Prices on Commodity Exchange

\begin{tabular}{|c|c|c|c|c|c|}
\hline Month & \begin{tabular}{|c|} 
Average Monthly \\
Market Price \\
P(tr) \\
\end{tabular} & \begin{tabular}{|c|} 
Monthly \\
Consumer Price \\
Indices \\
\end{tabular} & $\begin{array}{l}\text { Average Monthly } \\
\text { Indexed Price }\end{array}$ & \begin{tabular}{|c|}
$\begin{array}{c}\text { Rate of Fluctuation } \\
\text { of Monthly Market } \\
\text { Price ri(tr) }\end{array}$ \\
\end{tabular} & $\begin{array}{c}\text { Rate of Fluctuation } \\
\text { of Indexed Price } \\
\text { ri(in) }\end{array}$ \\
\hline Jan.08 & 16.00 & 100.00 & 16.00 & & \\
\hline Feb.08 & 15.78 & 100.70 & 16.11 & -1.38 & 0.69 \\
\hline Mar.08 & 14.65 & 101.20 & 16.31 & -7.16 & 1.24 \\
\hline \multicolumn{6}{|c|}{$v$} \\
\hline Jan.09 & 8.22 & 103.00 & 17.60 & 9.60 & 2.98 \\
\hline Feb.09 & 9.15 & 102.30 & 18.00 & 11.31 & 2.27 \\
\hline Mar.09 & 8.35 & 100.50 & 18.09 & -8.74 & 0.50 \\
\hline \multicolumn{6}{|c|}{$v$} \\
\hline Okt.12 & 25.53 & 102.80 & 25.40 & -4.09 & 2.79 \\
\hline Nov.12 & 24.71 & 100.00 & 25.40 & -3.21 & 0.00 \\
\hline Dec.12 & 23.47 & 99.60 & 25.30 & -5.02 & -0.39 \\
\hline
\end{tabular}

Source: Author's Analysis according to Produktna berza Novi Sad, http://paragraf.rs/ statistika/26_stat_arh.htm

Rate of fluctuation of average monthly market price in February 2008 amounted to:

$$
r_{p 2}(t r)=\frac{P_{i(t r)}-P_{i-1(t r)}}{P_{i-1}(t r)}+100=\frac{15,78-16,00}{16,00} \cdot 100=1,38
$$

and the rate of fluctuation of average monthly indexed price in February 2008 amounted to:

$$
r_{p 2(\text { in })}==\frac{P_{i(\text { in })}-P_{i-1(i n)}}{P_{1-1}(\text { in })}=100=\frac{16,11-16,00}{16,00} \cdot 100=0,69
$$

The rates of price fluctuation during the entire period were calculated in the same way and, on the basis of computed rates of fluctuation, it was possible to determine their expected values, variances, standard deviations and variation coefficients: 
Table 4. Average Value of Price Fluctuation Rates and Maize Price Volatility Indices per Annum

\begin{tabular}{|l|r|r|r|r|}
\hline \multicolumn{1}{|c|}{ Year } & Mean Value & ${\text { Variance } \boldsymbol{\sigma}^{2}}^{2}$ & $\begin{array}{c}\text { Standard } \\
\text { Deviation } \sigma\end{array}$ & \multicolumn{1}{c|}{$\begin{array}{c}\text { Variation } \\
\text { Coefficient V }\end{array}$} \\
\hline 2008 to 2012 (monthly average) & 1.17 & 104.27 & 10.30 & 8.80 \\
\hline $\begin{array}{l}\text { 2008 to 2012 (monthly average - } \\
\text { general index) }\end{array}$ & 0.78 & 0.65 & 0.81 & 1.04 \\
\hline
\end{tabular}

Source: Author's Analysis according to Produktna berza Novi Sad, http://paragraf.rs/ statistika/26_stat arh.htm

All the observed parameters - mean value, variance and/or standard deviation and variation coefficient are much lower with the prices indexed by the application of general consumer price index than in the case of retail price movements. Standard deviation, as a basic volatility measure, is almost 13 times lower when the prices are formed by applying the general index than when they are formed on the Commodity Exchange.

This is also illustrated by a graph of price fluctuation tendencies in the above mentioned cases- whereas the fluctuations of prices formed by applying the general index move mostly within a very narrow interval, around the mean value of 0.78 , the fluctuations of market prices show strong volatility.

Graph 3. Rates of Fluctuation of Average Monthly Maize Prices on Commodity Exchange

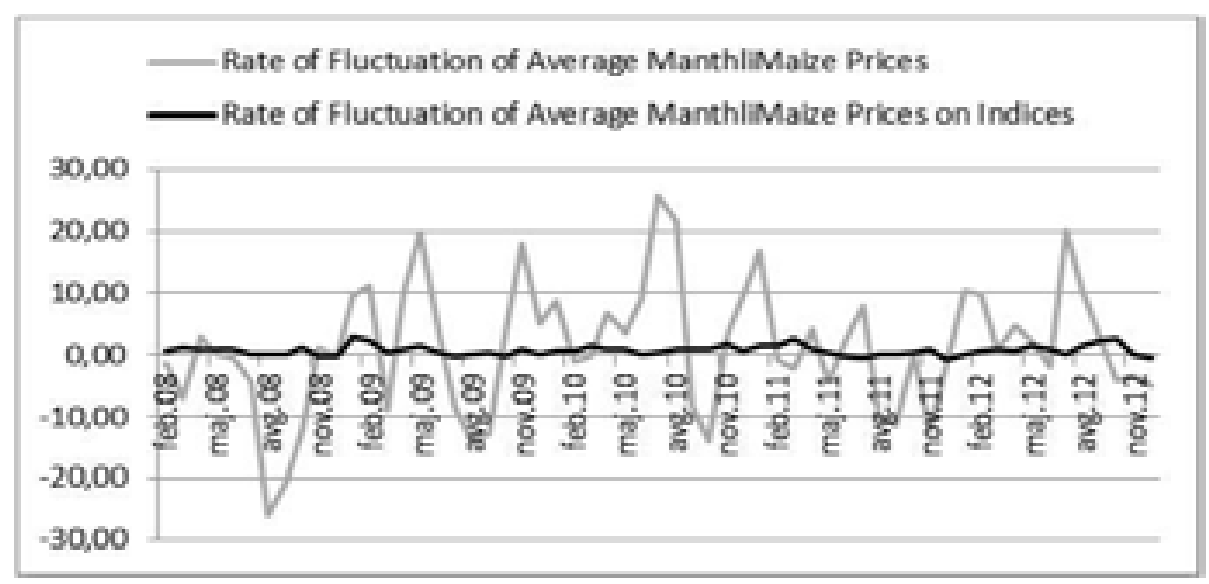

Source: Author's Analysis according to Produktna berza Novi Sad, http://paragraf.rs/ statistika/26_stat_arh.htm

Based on the results of applying the statistical methods and on the assumption that the prices of warehouse receipts will mainly follow the general index of consumer prices, we can conclude that the trade in warehouse receipts will operate to reduce the risk present in the maize production; this primarily refers to increasing the stability of price movements and the reduction of cyclical tendencies in the production of basic grains, which would ensure greater stability and safety in the supply of grains. 


\section{Conclusion}

A possible problem for the functioning of this system is the price of crops before and after the storage. As the given analysis has shown, it is necessary to have the growth of the market price of stored goods, from the moment of issuing the warehousing certificate to the final settlement and collection of the outstanding debt, so that all the participants in the system chain could achieve an economic gain. This is usually not the case in the countries where the price stability on the agricultural products market is maintained by the help of the government interventions and subsidies.

Direct government control of prices i.e. setting the top selling price for the strategic agricultural products, on the one hand and the lowest purchase prices, on the other, aims at protecting the consumers and maintaining the social peace, at the expense of the producer. The advocates of such a price policy find the basic reasons for using these measures in the fact that those are the strategically important goods, with a high-risk production. They also stress the need for mitigating the seasonal oscillations of prices inherent to agricultural products and that the agricultural production, specific as it is, requires crediting. However, the implementation of policy of guaranteed purchase prices for agricultural products, which are usually higher than the market prices, leads to the new imbalances. Subsidies granted to both the consumers and the producers finally lead to either the shortage or the hyper production on the market, which calls for the engagement of the Directorate for Buffer Stock, as a market stabilizer. The activities of the Directorate bring profit to those selling goods to it, mainly the processors and agricultural plants, but rarely to the agriculturers. Such activities of the Directorate add to the in-transparency and competitiveness of market economy.

Another problem lies in the fact that the basic precondition for the functioning of such a system is a regulated and organized market; in this case, the organized exchange market. Moreover, there is the need for the efficiency of such a market, which depends on the volume and value of the warehouse receipts to be quoted on it.

Development of trade on commodity exchanges and the growing inclusion of agricultural producers in the exchange business shall add to efficient price formation and certain purchase. Also, the information of prices on domestic market would become available to potential foreign buyers. This would much decrease the business risks for the maize (and/or other grain) producers, primarily by ensuring more stable movement of basic grain prices, regardless of whether their fluctuations are caused by the season's factor and/or various expectations of grain crops and their price tendencies. This would eventually improve the economic position of the grain producers, because the average difference in the price levels would much exceed the costs of using the warehouse receipts (such as warehousing, interest and/or insurance expenses).

There are, of course, certain cases when the prices of the warehouse receipts will not follow the movement of the general index of consumer prices; this is, in general, due to the lack of trust in the system of the government protective measures or due to the general disturbances in the movement of prices and inflation processes which could annul the positive effects of 
introducing the warehouse receipts. On the other hand, for the warehouse receipts to become a reality the government should make banks and other institutions dealing in the warehouse receipt financing absolutely certain that they will gain return on the invested funds and/or ensure, by issuing the government guarantees, that the investment risk becomes irrelevant. In accordance with the country specifics, we should initially focus on the limited and targeted assistance in drafting the law and by-laws which are necessary for the regular implementation of the System. The full programme implementation can begin after the government bodies participating in this process have confirmed their decision to adopt the relevant Law. The strong support by the local banks is key for the development of this programme. If the local banks lack in knowledge of the system of warehouse receipt financing, the programme should include their training as well, and the drafting of a pilot project. Any programme targeting the improvement of the warehouse receipt financing system should introduce the participants to the real life advantages of this system, quoting the experiences from the other countries and the relevant industry sectors, in order to convince them of the efficiency of this mechanism. Although the strong local support is necessary, there is no need to include either all or even majority of local banks. It is more efficient to work with one or a few dynamic groups, and we can assume that after these initiators have achieved a positive result, the others will follow their example.

\section{References}

1. Dunković, D. (2009): Finansiranje poljoprivredne proizvodnje putem skladišnice, Računovodstvo, revizija i financije, Zagreb, br. 9/09.

2. EBRD (2004), Grain Receipts Programme, Project Evaluation Department Special Study-N.PEO4-271S, November 2004, available at:

www.eastagri.org/files/warehouse.pdf

3. Hollinger, F., Rutter, L. (2009): The Use Warehouse Receipt Finance in Agriculture in EECA Countries, European Bank, FAO, Rome.

4. Mastilović, J., Janjić, E., Torbica, A., Pojić, M., Živančev, D., Kevrešan, Ž., Novaković, A., Radusin, T. (2011): Savremeni pristup upravljanju skladištem za zrnaste kulture, Univerzitet u Novom Sadu, Institut za prehrambenu tehnologiju, Novi Sad, available at: www.kompenzacionifond.gov.rs/file/pravilnici/Prirucnik_za_rad_javnih_skladista_za zrnaste kulture.pdf

5. Mathieson, D. J. (1989): Managing Financial Risks in Indebted Developing Countries, Vol. 69, IFM, Washington, D.C.

6. Muminović, S., Milićević, L., Zeremski, A. (2013): Rizici ulaganja u akcije i obaveznice, Ekonomski institut, Beograd.

7. Republički Zavod za statistiku (2013): Statistički godišnjak Republike Srbije, Beograd, str. 220.

8. Stanković, D. (2010): Komparativna analiza Kompenzacionog fonda u sistemu javnih skladišta poljoprivrednih proizvoda, Magistarski rad, Ekonomski fakultet Beograd. 
9. Stojanović, Ž. (2000): Hedžing strategija u funkciji menadžmenta u agroprivredi, Magistarski rad, Ekonomski fakultet Beograd.

10. Zakon o javnim skladištima za poljoprivredne proizvode, Službeni glasnik, br. 41, 2 jun 2009.

11. www.kompenzacioni fond.gov.rs, accessed at 29.1.2014.

12.http://paragraf.rs/statistika/26 stat arh.htm, accessed at 13.1.2014.

\title{
ROBNI ZAPIS U FUNKCIJI SMANJENJA TRŽIŠNOG RIZIKA ${ }^{10}$
}

\author{
Daliborka Jovičič ${ }^{11}$, Ljiljana Jeremić12, Lazar Milićević13, Aleksandar Zeremski ${ }^{14}$
}

\section{Rezime}

Proizvodnja žitarica podleže tržišnom riziku u značajnoj meri zbog svoje elastične tražnje. Cena žitarica ima ciklično kretanje i značajno pada u periodima žetve kao posledica velike ponude i nedovoljne tražnje.Sama specifičnost poljoprivredne proizvodnje dovodi do toga da su poljoprivrednici prinuđeni da prodaju svoje proizvode po nepovoljnim uslovima da bi nastavili proizvodnju. Sistem javnih skladišta pruža mogućnost poljoprivrednicima, koji do sada nisu mogli da koriste bankarske kredite u cilju nastavka proizvodnje, da uz pomoć robnih zapisa, koji imaju ulogu koleterala, na efikasniji način dođu do potrebnih sredstava.

Na osnovu rezultata dobijenih primenom statističkih metoda (varijanse $i$ standardne devijacije), kao mere tržišnog rizika pod predpostavkom da će cene robnih zapisa približno pratiti opšti indeks potrošačkih cena, može se zaključiti da će trgovina robnim zapisima u značajnoj meri uticati na smanjenje rizika u proizvodnji žitarica. Pozitivni efekti bi se manifestovali kroz stabilizaciju cena, umanjenje cikličnosti u kretanju proizvodnje osnovnih žitarica $i$ u krajnjoj liniji na prehrambenu sigurnost zemlje.

Ključne reči: robni zapis, tržišni rizik, varijansa, standardna devijacija.

10 Ovaj rad je deo istraživanja na projektu br. 179001 koji finansira Ministarstvo prosvete, nauke i tehnološkog razvoja Republike Srbije.

11 Mr Daliborka Jovičić, koordinator poslova statističkog izveštavanja, Kompanija „Dunav osiguranje“a.d.o., Kolarčeva 7, 11000 Beograd, Srbija, Telefon: +381 113037 233, E-mail: daliborka.jovicic@dunav.com

12 Dr Ljiljana Jeremić, profesor Univerziteta Singidunum, Danijelova 32, 11000 Beograd, Srbija, Telefon: +381 113093 220, E-mail: ljjeremic@singidunum.ac.rs

13 Lazar Milićević, koordinator poslova upravljanja rizicima aktive i pasive, Kompanija „Dunav osiguranje“a.d.o., Kolarčeva 7, 11000 Beograd, Srbija, Telefon: +381 113037 233, lmilicevic@dunav.com

14 Dr Aleksandar Zeremski, naučni saradnik, Ekonomski Institut Beograd, Kralja Milana 16, 11000 Beograd, Srbija, Telefon: +381 113613 049, E-mail: aleksandar.zeremski@ecinst.org.rs

EP 2014 (61) 2 (347-365) 